DOI: $10.19195 / 0137-1134.114 .20$

\author{
JAN JEŻEWSKI \\ Wyższa Szkoła Finansów i Zarządzania w Warszawie \\ jan.jezewski@gmail.com
}

\title{
GENEZA KONSTRUKCJI NADZORU NAD SAMORZĄDEM TERYTORIALNYM W DEPARTAMENCIE WE FRANCJI
}

\begin{abstract}
Abstrakt: Celem artykułu jest omówienie ścisłego związku między centralizacją ustroju państwa a utrzymaniem władzy — na podstawie badań przedstawionych w znakomitym dziele Alexisa de Tocqueville Dawny ustrój i rewolucja. Tocqueville połączył umiejętnie dwa aspekty dostrzegane w dyskusji o genezie nadzoru nad samorządem terytorialnym — aspekt ochrony praw człowieka i obywatela oraz aspekt rewolucji, która przejęła większość zmian umacniających centralizm, umożliwiające monarchii budowanie konstrukcji podtrzymania władzy. Celem podjętych tu rozważań jest przypomnienie stosunkowo rzadko przytaczanych fragmentów tekstów zawierających uzasadnienie zdecydowanych ocen, którymi Tocqueville zamykał analizę praktyki ustrojowej monarchii w różnych dziedzinach, ukazując ponadczasową rolę centralizacji w umacnianiu władzy absolutnej. Wśród kilku opisanych sytuacji należy podkreślić znaczenie niezawisłych sądów w ochronie praw jednostki. Artykuł zamyka sumaryczne ukazanie faz przekształceń ustrojowych nadzoru nad samorządem departamentu we Francji.
\end{abstract}

Słowa kluczowe: republika, rewolucja, centralizacja, nadzór, departament, prawa człowieka

W doktrynalnych ocenach genezy nadzoru nad samorządem terytorialnym we Francji, wiązanej ze zmianami niesionymi przez rewolucję, pojawiają się, wśród wielu innych, dwa stosunkowo łatwo dostrzegalne aspekty: jest to aspekt prawnych gwarancji praw człowieka i obywatela oraz aspekt kształtowania ustroju państwa - nasilającej się lub słabnącej centralizacji administracji. Są to aspekty różne, wynikające $\mathrm{z}$ odmiennych motywów i kształtowane w odrębnych uwarunkowaniach intelektualnych, które jednak są powiązane, tworząc układ wzajemnego zasilania. Idea praw człowieka i obywatela stała się we Francji jednym z głównych impulsów i uzasadnień rewolucji; utrwalona przez stulecia tradycja państwa absolutystycznego zmuszała jednak do nieustannego zabiegania o potwierdzanie tej idei w zmieniających się układach politycznych kolejnych republik. Konstytucje podtrzymywały pogląd o dominacji ustawy w systemie prawa (jakobińska konstytucja z 24 czerwca 1793 roku była określona mianem „hymnu 
dla ustawy"1); jak trafnie zauważa J. Baszkiewicz, Francja była obciążona przekonaniem wyprowadzonym z poglądów J.J. Rousseau, że ustawa daje wyraz zaufania do suwerena, którym jest naród, oraz do stanowionego przez niego prawa. Dlatego właśnie deklaracja z 1789 roku oddawała francuskiemu ustawodawcy decyzję o sposobie korzystania z jej postanowień. „Twórców Deklaracji nie owiewał nawet cień podejrzenia, że ów ustawodawca może ujawnić złą wolę, interesowność lub zwykłą głupotę"

Centralizacja administracji otwierała inną, nieporównanie szerszą perspektywę oceny warunków, w jakich kształtowała się konstrukcja nadzoru nad samorządem terytorialnym we Francji. Centralizację stworzył dawny, przedrewolucyjny ustrój. Rewolucja początkowo odrzuciła dawne wzory, by w kolejnych fazach przekształceń ustrojowych państwa do nich powrócić i wykorzystać z pełną konsekwencją. Liczne publikacje poświęcone centralizacji pojawiły się w połowie XIX stulecia, po znanej konfuzji dekretu Ludwika Napoleona z 25 marca 1852 roku o decentralizacji administracji, który dotyczył wyłącznie przekazania prefektom niektórych kompetencji ministrów — był więc manifestacją dekoncentracji, znanej $\mathrm{z}$ wielu opisów - ale jeszcze tak nie nazywanej ${ }^{3}$. Jak wiadomo, centralizacja stała się w nauce prawa publicznego przedmiotem teoretycznej refleksji, wówczas gdy pojawiła się jej ideowa, polityczna, a wreszcie prawna alternatywa - decentralizacja.

Wymienione tu oba aspekty zostały ujęte łącznie w przełomowej książce, którą A. de Tocqueville opublikował w 1856 roku (L'Ancien régime et la Révolution), po długim okresie intensywnych badań historycznych i komparatystycznych, zmieniając upowszechniony pogląd o przyczynach i skutkach rewolucji i ukazując jej ideowe podłoże. Celem podjętych tu rozważań jest przypomnienie stosunkowo rzadko przytaczanych fragmentów tekstów zawierających uzasadnienie zdecydowanych ocen, którymi Tocqueville zamykał analizę praktyki ustrojowej monarchii w różnych dziedzinach — i które, w sposób zaskakujący, można odnosić do kwalifikowania współczesnych zabiegów politycznych i prawnych, demolujących (między innymi w Polsce) konstytucyjny ustrój państwa.

Trzeba przypomnieć podstawową tezę, iż rewolucja przejęła większość zmian, umacniających centralizm, którymi monarchia budowała konstrukcję podtrzymania władzy. Istotny jest również pogląd, podkreślony przez F. Fureta, autora wstępu do polskiego wydania z 1970 roku, iż radykalna rewolucja demokratyczna obaliła dawny ustrój, zanim doszło do rewolucji, ,siła o odmiennym charakterze, lecz o podobnych skutkach działała w tym samym kierunku i przygotowała

1 A. Sulikowski, Konstytucja w systemie źródet prawa V Republiki Francuskiej, „Prawo” 286, 2003, s. 22.

2 J. Baszkiewicz, Francja w Europie, Wrocław 2006, s. 99.

${ }^{3}$ L. Aucoc, Introduction à l'étude du droit administratif. Première conférence faite à l'Ecole Impériale des Ponts et Chaussées, Paris 1865, s. 64. 
grunt dla Rewolucji”4. Kolejne fazy rewolucji, z niewielkimi i krótkotrwałymi wyjątkami, zmierzają do centralizacji państwa; jej ukoronowanie to powrót rządu, pisze Tocqueville w przedmowie do książki ${ }^{5}$, który silniejszy i znacznie bardziej absolutny niż ten, który rewolucja obaliła, ,ponownie przejmuje i skupia w swoich rękach całą władzę, [...] odbierając narodowi zdolność rządzenia sobą, najważniejsze gwarancje prawne, wolność myślenia, mówienia i pisania, czyli to, co było najcenniejsze i najszlachetniejsze w zdobyczach roku 89 [...]". Wartości utracone przypisuje Tocqueville arystokracji, zniszczonej przez monarchię, ale też w arystokracji, stosownie do swej przynależności społecznej, sytuuje wartość wolności, niesioną przez hasła rewolucji. W tym można dostrzec ideową płaszczyznę, zarysowaną w kolejnych deklaracjach praw człowieka i obywatela. „Tylko wolność bowiem może wyprowadzić obywateli z izolacji, w której każe im żyć właśnie niezależność ich położenia, i zmusić ich, by się do siebie zbliżyli; tylko ona co dzień ich zagrzewa i gromadzi przez konieczność porozumiewania się, przekonywania i zjednywania nawzajem w prowadzeniu spraw wspólnych"6.

W obszernym zestawie tematów ukazujących przemożne dążenie władzy absolutnej do opanowania życia prowincji, kilka dotyczy mechanizmów przejmowania organów lokalnych w sposób pośredni lub bezpośredni; stopień uzależnienia przesądzał o postawie lokalnych urzędników wobec kontrolerów lub przełożonych. W rozdziale, którego tytuł podkreśla, że centralizacja jest dziełem dawnego ustroju, Tocqueville opisuje, jak w dłuższym okresie poprzedzającym rewolucję $\mathrm{z}$ chaosu ustrojowego na poziomie lokalnym i centralnym stopniowo wyłoniła się rada królewska (le conseil du roi), która, z łaski króla, skupiła kompetencje ustawodawcze, czuwała nad funkcjonowaniem niższych organów władzy, wymierzała sprawiedliwość — a zarazem była złożona z ludzi, którzy jedynie wyrażali swoje zdanie, gdyż o wszystkim decydował sam król, nawet wtedy, gdy na pozór wyrokowała rada. „Działa zwykle dyskretnie i po cichu, nie chełpiąc się swoją władzą, [...] tak potężna, że dotyka wszystkiego, a zarazem tak niewidoczna, że historia ledwie ją dostrzega"7. Władzę terytorialną sprawują intendenci nazywani komisarzami zamiejscowymi (commisaire dèparti); powoływani przez rząd spomiędzy niższych urzędników rady stanu są zawsze odwoływalni. „Intendent koresponduje ze wszystkimi ministrami; jest w prowincji jedynym wykonawcą wszystkich rozkazów rządu". Kryjąc się za resztkami dawnej arystokracji feudalnej, korzystali z jej blasku i pozycji, chociaż byli dla niej ,przedstawicielami natrętnej władzy, ludźmi nowymi, którzy mieli rządzić mieszczanami i chłopami, ludźmi, których traktowali z góry"8. Centralizacja wdzierała się we wszystkie dziedziny lokalnego

4 F. Furet, Wstęp, [w:] A. de Tocqueville, Dawny ustrój i rewolucja, Kraków 1994, s. 9.

5 A. de Tocqueville, op. cit., s. 24.

6 Ibidem, s. 27.

7 Ibidem, s. 64.

8 Ibidem, s. 66. O zadaniach intendentów i ich podziale na zadania sądowe, zadania policyjne i zadania fiskalne pisze również J.-B. Albertini, La déconcentration. L'administration territoriale 
życia społecznego. W sądownictwie pojawił się zamęt wynikający z konfliktów kompetencyjnych między radą a sądami — rada uchylała rozporządzenia porządkowe obowiązujące na różnych częściach terytorium lub w miejscowościach i

wydawała co dzień przepisy ogólne, obowiązujące dla całego królestwa — albo w materiach innych niż te, w których orzekały sądy, albo też w tych samych, gdzie orzekała inaczej [...]. Nie ma prawie takiej dziedziny gospodarki społecznej czy organizacji politycznej, której by w ciągu czterdziestu lat poprzedzających rewolucję nie zmieniły postanowienia rady ${ }^{9}$.

Intendenci przejęli między innymi w szerokim zakresie udzielanie pomocy społecznej; rada w kolejnych rozporządzeniach nakazywała otwieranie w miejscowościach wskazanych przez intendenta warsztatów dobroczynnych, dających zatrudnienie najuboższym: „miłosierdzie pełnione z tak daleka było często ślepe albo kapryśne, a zawsze bardzo niewystarczające"10.

Dziełem monarchicznego absolutyzmu był także nadzór administracyjny. $\mathrm{Na}$ mocy ustawy z 1764 roku o administracji miast powoływane są dwa zgromadzenia: zarząd miejski oraz zgromadzenie ogólne. Zarząd działa kolegialnie, co oznacza, że zbiorowo ponosi odpowiedzialność za podjęte decyzje — może to oznaczać zamknięcie drogi do egzekwowania przez mieszkańców podjętych zobowiązań. Zgromadzenie ogólne ulega stopniowo degeneracji; ginie dawna tradycja wyboru członków zgromadzenia przez cały lud in corpore - są oni desygnowani przez lokalne ugrupowania, przy czym maleje liczba przedstawicieli cechów rzemieślniczych. Narasta obojętność mieszkańców wobec spraw miejskich, zawodzą próby poszerzenia ich udziału w wyborach. Tocqueville daje twardą ocenę tej sytuacji. „Niemal wszyscy władcy, którzy zniszczyli wolność, próbowali z początku utrzymać jej formy [...], łudzili się, że uda im się połączyć silę moralną, jaką zawsze daje publiczne zaufanie, z wygodami, które zapewnić może tylko władza absolutna". Ich porażki wskazują, ,że nie da się długo utrzymywać kłamliwych pozorów tam, gdzie ich nie potwierdza rzeczywistość"11. Dłuższy wywód o wartościach, jakie przez dziesięciolecia były chronione przez parafie w różnych krajach Europy, zamyka konkluzja pesymistyczna: odłączona od pana, ,ale uchwycona potężną dłonią przez państwo, stała się we Francji tym, co się postaram opisać”. Trwająca dziesiątki lat ewolucja doprowadziła do utrwalenia w XVIII wieku dwu poborców podatkowych - poborcy (collecteur) i syndyka (syndic).

„Poborca zbiera podatek majątkowy na bezpośredni rozkaz intendenta. Syndyk, pod codziennym nadzorem intendenckiego subdelegata, reprezentuje go we wszystkich sprawach mających związek z porządkiem publicznym i zarządzaniem". Wycofanie się pana feudalnego z zarządzania sprawami wsi spowodowało,

dans la réforme de l'état, Paris 1997, s. 7. Zob. też F. Burdeau, Histoire de l'administration française. Du $18^{e}$ au $20^{e}$ siècle, Paris 1994, s. 28-31.

9 A. de Tocqueville, op. cit., s. 68.

10 Ibidem, s. 69.

11 Ibidem, s. 73. 
że do miasta uciekali niemal wszyscy zamożniejsi i bardziej oświeceni mieszkańcy — „poza nim we wsi zostawało już tylko stado ciemnych i nieokrzesanych chłopów, niezdolnych do podołać administrowaniu wspólnymi sprawami [...]. Dokumenty administracyjne z osiemnastego wieku pełne są skarg na nieudolność, inercję i nieuctwo parafialnych poborców i syndyków" 12 . Z tym wszystkim parafie, aż do rewolucji, zachowują w swych zwyczajach coś z demokratyzmu z czasów średniowiecza. Gdy dzwon kościelny zwołuje chłopów przed kościelne wrota, każdy ma prawo tu przyjść i wypowiedzieć swoje zdanie, a wezwany pisarz umieści je w protokole. Ale zebranie to mogło dojść do skutku dopiero po uzyskaniu specjalnego zezwolenia intendenta i zależnie od jego dobrej woli (sous son bon plaisir).

Choćby jakaś decyzja zapadła jednogłośnie, zgromadzenie nie mogło ani się opodatkować, ani nic sprzedać, ani kupić, ani wydzierżawić, ani wystąpić do sądu bez zezwolenia królewskiej rady. Żeby naprawić szkody wyrządzone przez wichurę w kościelnym dachu czy podźwignąć walący się mur plebanii, trzeba było uzyskać postanowienie tej rady ${ }^{13}$.

Przykład ten wskazuje, że rządy „najbardziej absolutne mogą się złączyć z niektórymi formami najskrajniejszej demokracji, jak do ucisku dochodzi jeszcze śmieszność wynikająca z udawania, że się ucisku nie widzi"14. Tak więc za dawnego ustroju, i dziś, nie było we Francji żadnego podmiotu otwartego na społeczność, który mógłby „samodzielnie kierować własnymi sprawami i dowolnie administrować własnym majątkiem. A więc jak dziś, tak i wówczas administracja trzymała wszystkich Francuzów pod kuratelą i choć nie istniało jeszcze to bezwstydne określenie, rzecz sama już była"15.

Pozostaje sprawa sądownictwa administracyjnego. Sądy, chroniące swą niezawisłość, w ostatnim stuleciu monarchii stały się ofiarą ewokacji:

Jego Królewska Mość rozkazuje także, by wszelkie sprawy i spory, które wykonanie niniejszego zarządzenia spowodować może, były wraz z podaniem okoliczności i spraw z tym związanych wnoszone przed intendenta, by on je rozsądził z prawem apelacji do rady. Zabrania się rozpoznawania ich naszym sądom i trybunałom ${ }^{16}$.

Praktyka tworzenia sądów wyjątkowych umacniała przekonanie, że wszystkie procesy, w których w grę wchodzi interes publiczny lub pojawia się konieczność interpretacji aktu administracyjnego, są wyłączone z kompetencji sądów zwykłych, powołanych do rozstrzygania sporów dotyczących interesów prywatnych. Tocqueville przytacza opinie jednego z intendentów: „Zwykły sędzia — mówi — musi się trzymać sztywnych zasad, które mu nakazują potępić postępek sprzecz-
12 Ibidem, s. 76.
13 Ibidem, s. 77.
14 Ibidem.
15 Ibidem, s. 78.
16 Ibidem, s. 80. 
ny z prawem; ale rada mając pożytek na oku zawsze może naruszyć przepisy”. Opinię tę wzmacnia inny intendent: „Chociaż chodzi tutaj jedynie o prawa osób prywatnych, których rozpoznawanie należy do sądów, Jego Królewska Mość może zawsze, ilekroć zechce, zastrzec sobie rozpoznawanie sprawy każdego rodzaju, nie potrzebując się tłumaczyć z przyczyn" ${ }^{17}$. Dokonany przez rewolucję podział sfer kompetencyjnych sądów powszechnych i administracji został uznany za sukces; jednak proces, który do tego doprowadził, spotkał się z gorzką oceną:

To prawda, że my wyparliśmy sądownictwo z dziedziny administracji, w którą mu dawny ustrój zupełnie niesłusznie pozwolił wkroczyć; ale równocześnie rząd, jak się okazuje, nieustannie wciskał się w naturalną sferę działania sądownictwa, a my zostawiliśmy go tam, jak gdyby brak podziału władzy nie był tu równie niebezpieczny, a nawet szkodliwszy; bo wtrącanie się sądownictwa w administrację szkodzi jedynie interesom, podczas gdy wtrącanie się administracji w sądownictwo deprawuje ludzi i czyni z nich buntowników i służalców jednocześnie ${ }^{18}$.

Ale to właśnie sądy zapewniły, że głos uciśnionych mógł się rozlegać; obciążone licznymi wadami sądownictwo było wolne od serwilizmu wobec władzy, który jest formą sprzedajności, i to najgorszą. Język sądowy „zachowywał jeszcze wówczas cechy starej francuszczyzny, w której lubiano nazywać rzeczy po imieniu, często zdarzało się, że sądownicy bez ogródek nazywali postępowanie rządu despotyzmem i samowolą". Sądy wkraczały niekiedy w zakres spraw rządowych; służyło to niejednokrotnie obronie wolności jednostek; , ,było to wielkie zło, ograniczające zło jeszcze większe"19.

Dokonując podsumowania analiz ustrojowych, Tocqueville podejmuje próbę zdefiniowania centralizacji. Usytuowany w centrum królestwa jeden organ rządzi administracją publiczną w całym kraju; jeden minister skupia pełnię kompetencji w dziedzinie spraw wewnętrznych; w poszczególnych prowincjach urzędnik podległy rządowi decyduje o ich szczegółowym wykonaniu i kieruje podległym personelem; wszelkie spory, w których pojawiają się interesy administracji i jej urzędników, rozstrzygają trybunały specjalne. „Cóż to jest, jeśli nie dobrze nam znana centralizacja? [...]. Od tamtej pory niczego istotnego nie musiano ani do niej dodać, ani odjąć; dość było zburzyć wszystko, co się dookoła wznosiło, by się ukazała taka, jaką widzimy"20. Monarchii udało się opróżnić przestrzeń między nią a obywatelami, usuwając wszelkie władze pośrednie - władza jawi się ludziom z oddali ,jako jedyna sprężyna społecznej machiny, jedyny i nieodzowny czynnik życia publicznego" 21 .

17 Ibidem, s. 80-81.

18 Ibidem, s. 81.

19 Ibidem, s. 135.

20 Ibidem, s. 84. „te same funkcje były wykonywane przez tych samych funkcjonariuszy [...]. Sądzili i administrowali w imieniu króla, potem w imieniu republiki, wreszcie w imieniu cesarza. Potem, gdy fortuna zatoczyła koło, znowu zaczęli administrować i sadzić dla króla, dla republiki i dla cesarza — ciągle ci sami, tak samo; bo i cóż dla nich znaczyło miano władcy?", ibidem, s. 210.

21 Ibidem, s. 92. 
Trudno więc się dziwić, że widmo centralizmu towarzyszyło od początku pojawieniu się departamentu we Francji. Może warto tu przypomnieć, że departamenty utworzone 26 lutego (dekret Zgromadzenia o podziale terytorium na 83 departamenty) i 4 marca 1790 roku (zatwierdzenie dekretu przez króla) przechodziły kolejne fazy nasilającej się i słabnącej ingerencji rządu — w dużej mierze zależało to od sytuacji zewnętrznej państwa. Krótki okres rzeczywistej, choć ryzykownej samodzielności gmin i departamentów został oparty na wcześniejszej ustawie z 22 grudnia 1789 roku, która określiła między innymi władze administracji i tryb ich desygnowania $\mathrm{w}$ departamencie. W myśl ustawy w głównym mieście każdego departamentu będzie ustanowione zgromadzenie wyższe pod nazwą , administracja departamentu" (dystryktu). Administratorzy departamentu w liczbie 36 byli wybierani na dwa lata w elekcji dwustopniowej; ośmiu spośród nich, desygnowani na podstawie ich staranności, tworzyło dyrektoriat, organ wykonawczy kolegialny, działający stale. Inni konstytuowali radę, organ uchwałodawczy, odbywający sesję w jednym miesiącu każdego roku. Prokurer generalny — syndyk, pochodzący także z wyborów - uczestniczył we wszystkich posiedzeniach organów departamentu, bez udziału w głosowaniach, z zadaniem prowadzenia spraw i żądania przestrzegania ustaw. Gminy i departamenty działały praktycznie bez nadzoru (wyjątkiem był teoretyczny nadzór sprawowany przez dyrektoriat departamentu) - co było źródłem narastającej anarchii. Kolejne przekształcenia ustrojowe (poczynając od dyrektoriatu) prowadziły do umacniania podległości organów lokalnych rządowi; apogeum tego procesu to centralistyczna konsolidacja napoleońska (jak ją określa F. Burdeau ${ }^{22}$ ), i następujący po niej, trwający dziesiątki lat, powrót do odbudowy samorządu terytorialnego. Jego kulminacją była szeroko opisana reforma decentralizacyjna, wprowadzona między innymi ustawą z 2 marca 1982 roku, oddająca decyzje dotyczące legalności działania gmin, departamentów i regionów sądom administracyjnym.

Przytoczone wybrane fragmenty dzieła A. de Tocqueville'a nie pozostawiają wątpliwości, że centralizm był (i pozostał) instrumentem władzy absolutnej; dziś możemy powiedzieć, że jest również skutecznym sposobem umacniania partyjnej władzy autorytarnej w Polsce — gdyż czas oczekiwania na jej nadejście już minął. Już ją mamy.

22 F. Burdeau, op. cit., s. 72 n. 


\title{
THE GENESIS OF THE SUPERVISORY STRUCTURE OF TERRITORIAL SELF-GOVERNMENT IN THE DEPARTMENT IN FRANCE
}

\begin{abstract}
Summary
The aim of the article is to discuss the close relationship between the centralization of the state system and the maintenance of power - based on the research presented in the excellent work of Alexis de Tocqueville, The Old Regime and the Revolution. Tocqueville skilfully combined two aspects perceived in the discussion about the genesis of supervision over territorial self-government: the aspect of protection of human and civil rights and the aspect of the Revolution, that took over most of the changes that strengthened the centralism with which the monarchy built up the structure of maintaining power. The aim of the considerations discussed here is to recall the relatively rarely mentioned passages of the texts, that justify the decisive assessments with which Tocqueville closed the analysis of the systemic practice of the monarchy in various fields, showing the timeless role of centralization in strengthening absolute power. Among the several described situations, the importance of independent courts in the protection of individual rights should be emphasized. The article is closed with the summary of the phases of systemic transformation of supervision over the department's self-government in France.
\end{abstract}

Keywords: republic, revolution, centralization, supervision, department, human rights

\section{BIBLIOGRAFIA}

Albertini J.-B., La déconcentration. L'administration territoriale dans la réforme de l'état, Paris 1997.

Aucoc L., Introduction à l'étude du droit administratif. Première conférence faite à l'Ecole Impériale des Ponts et Chaussées, Paris 1865.

Baszkiewicz J., Francja w Europie, Wrocław 2006.

Burdeau F., Histoire de l'administration française. Du $18^{e}$ au $20^{e}$ siècle, Paris 1994.

Furet F., Wstęp, [w:] A. de Tocqueville, Dawny ustrój i Rewolucja, Kraków 1994.

Sulikowski A., Konstytucja w systemie źródeł prawa V Republiki Francuskiej, „Prawo” 286, 2003. Tocqueville A. de, Dawny ustrój i rewolucja, Kraków 1994. 